\title{
REGIONALIZATION BASED ON WATER CHEMISTRY AND PHYSICOCHEMICAL TRAITS IN THE RING OF CENOTES, YUCATAN, MEXICO
}

\author{
Rosela Pérez-Ceballosi*, Julia Pacheco-Ávila², Jorge I. Euán-Ávila ${ }^{1}$, And \\ HÉctor HERnÁNDEZ-AranA ${ }^{3}$
}

\begin{abstract}
Assessing water quality in aquifers has become increasingly important as water demand and pollution concerns rise. In the Yucatan Peninsula, sinkholes, locally known as cenotes, are karst formations that intercept the water table. Cenotes are distributed across the peninsula, but are particularly dense and aligned along a semicircular formation called the Ring of Cenotes. This area exhibits particular hydrogeological properties because it concentrates, channels, and discharges fresh water toward the coasts. In this study, we identify spatial and temporal variations in chemical and physical variables at twenty-two cenotes to identify groups that share similar characteristics. Water samples from each cenotes were taken at three depths $(0.5$, 5.5, and $10.5 \mathrm{~m}$ ) and during three seasons (dry, rainy, and cold-fronts season). Field measurements of $\mathrm{pH}$, temperature, electrical conductivity, and dissolved oxygen were taken, and the concentrations of major ions $\left(\mathrm{K}^{+}, \mathrm{Na}^{+}, \mathrm{Mg}^{2+}, \mathrm{Ca}^{2+}, \mathrm{HCO}_{3}^{-}, \mathrm{SO}_{4}^{2-}, \mathrm{Cl}^{-}\right.$ and $\mathrm{NO}_{3}^{-}$) were quantified. Identifying regions of the cenotes were done by applying multivariate statistical techniques (PCA, PERMANOVA, CAP). The chemical variables revealed spatial trends among the cenotes. We identified three main regions. Region 1 is associated with sea-water encroachment and high levels of sulfate that travel through preferential groundwater flowpaths from evaporites in the southern Yucatan Peninsula; Region 2 is a recharge zone, and Region 3 is characterized by sea water encroachment and by the high chemical and physical variability associated with groundwater flow from the east.
\end{abstract}

\section{INTRODUCTION}

Karst aquifers are characterized by having compact and soluble carbonate rocks in which the dissolution process (i.e., karstification) forms conduits and caverns through which groundwater flows (Antigüedad et al., 2007; Custodio and LLamas, 1983, p. 1495; Fernández et al., 2003; Moore et al., 2009). Rainfall quickly filters through karst surface features and enters the aquifer, leading to the storage of enormous quantities of water. In most karst regions, these reservoirs are vital water sources for human consumption, agriculture, livestock raising, and industry, among other uses. Karst aquifers therefore constitute a constraining input in the development of regions and even countries (Pacheco et al., 2004).

Karst systems' high permeability allows substances such as nutrients, metals, hydrocarbons, and bacteria to rapidly enter the aquifer. These substances, including contaminants, are distributed throughout the subterranean flow network, from which they are frequently discharged into the sea. Karst systems with a direct marine connection are also exposed to a serious risk of seawater encroachment as freshwater is extracted and saline water steadily advances into the system (Fernández et al., 2003).

Groundwater contains dissolved substances, largely in an ionic state. Major ions include sodium $\left(\mathrm{Na}^{+}\right)$, calcium
$\left(\mathrm{Ca}^{2+}\right)$, magnesium $\left(\mathrm{Mg}^{2+}\right)$, potassium $\left(\mathrm{K}^{+}\right)$, chloride $\left(\mathrm{Cl}^{-}\right)$, sulfate $\left(\mathrm{SO}_{4}^{2-}\right)$, bicarbonate $\left(\mathrm{HCO}_{3}^{-}\right)$, and nitrate $\left(\mathrm{NO}_{3}^{-}\right)$. The concentrations of these ions can be used to understand the chemistry of groundwater and its interaction with the subterranean environment, helping to identify the possible existence of chemical processes (Custodio and Llamas, 1983, p. 1020).

The Yucatan Peninsula is a large karst zone, with the main karst characteristic being sinkholes. Sinkholes are locally known as cenotes and can be found across the peninsula, but are particularly abundant in a semi-circular formation in the north-central portion of Yucatan state. This Ring of Cenotes (RC) is the edge of the terrestrial portion of the surface expression of the Chicxulub meteorite impact crater (Penfield and Camargo, 1981; Perry et al., 1989; Hildebrand et al., 1995; Perry et al., 1995; Marín et al., 2004). The RC was proposed in 2008 as a Ramsar site for conservation and rational use (Gobierno del Estado de Yucatan, 2008).

\footnotetext{
* Corresponding Author, rosela.perezc@gmail.com

${ }^{1}$ Centro de Investigación y de Estudios Avanzados del Instituto Politécnico Nacional Unidad Mérida, Antigua Carreta a Progreso Km. 6, Aportado Postal 73, Cordemex, 97310, Mérida, Yucatán, México

${ }^{2}$ Universidad Autónoma de Yucatán Facultad de Ingeniería, Av. Industrias no Contaminantes por Periférico Norte Apartado Postal 150 Cordemex, 97310, Mérida, Yucatán, México

${ }^{3}$ El Colegio de la Frontera Sur, Ave. Centenario Km 5.5. Chetumal, Quintana Roo México
} 


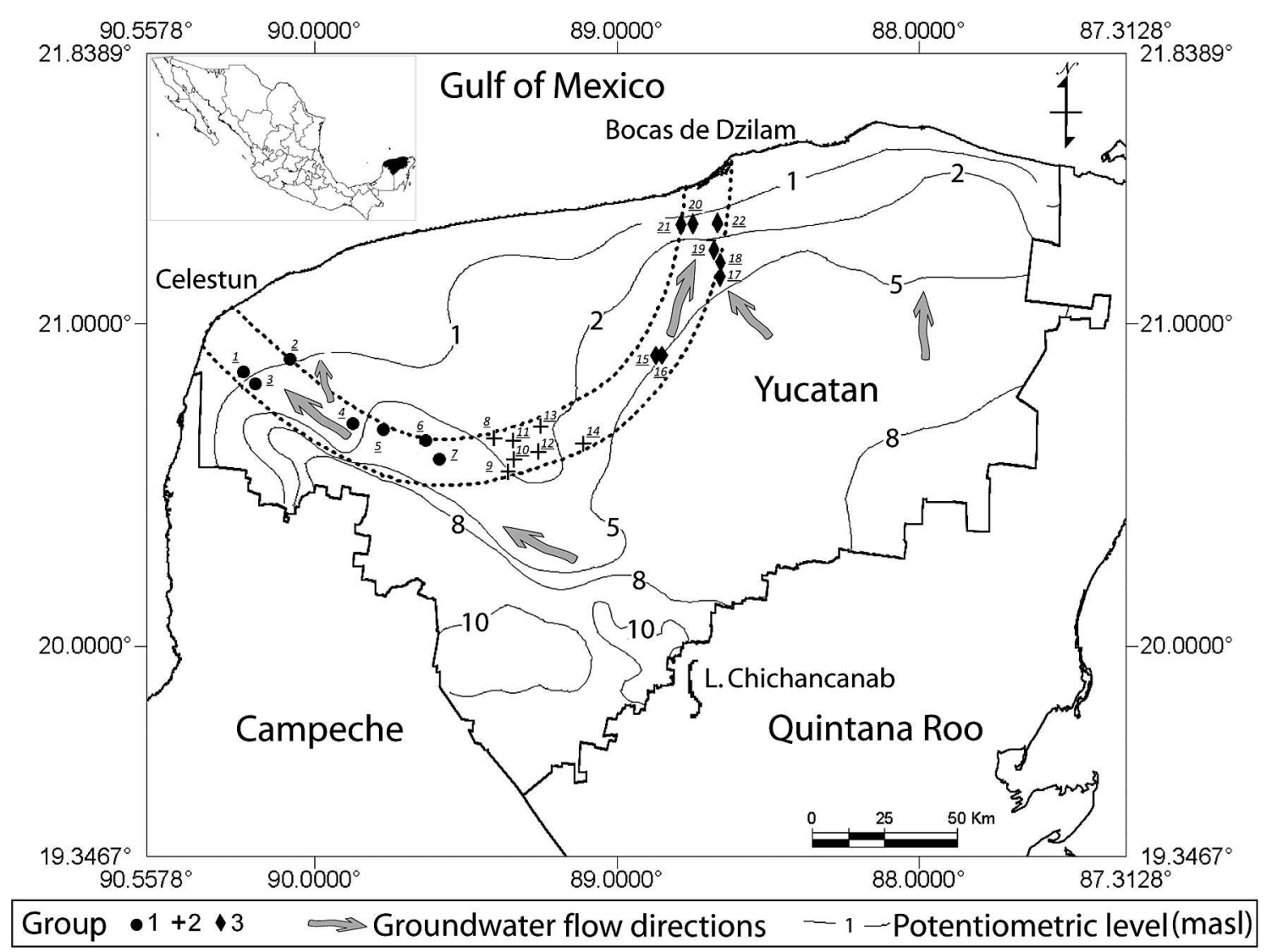

Figure 1. Study area in Yucatan state, Mexico, showing groundwater main flow directions, isopotentiometric levels (msal) and spatial distribution of the twenty-two sampled cenotes in the groups discussed in the text (adapted from SARH, 1989 and Perry et al., 2002).

The RC has been the focus of a number of hydrogeological studies. Using hydraulic gradients, Marín and Perry (1994) identified the RC as a zone of high permeability, which they linked to the Chicxulub crater. Hildebrand et al. (1995) determined the size of the crater and suggested that the formation of the RC was closely linked to a depression at the crater's edge. Steinich et al. $(1996,1997)$ defined the RC as a system with special hydrogeological properties, such as high permeability and subterranean-river behavior that concentrates, transports, and discharges water toward the coast near Celestún and Dzilam de Bravo. Using hydrochemical and hydrogeological data, they also determined that the zone is divided into two watersheds near its central portion. Finally, they identified groundwater flow as moving from southeast to northwest. Perry et al. (2002) reported that most groundwater of the Yucatan aquifer is in approximate chemical equilibrium with calcite and dolomite, but stated that other minerals were subsaturated. Using strontium isotopes, Perry et al. (2009) demonstrated that the water arriving at the western edge of the RC originates near Chichancanab lagoon in the southern part of the peninsula, flows through a permeable fault zone manifested on the surface by the Ticul Ridge, and finally discharges into the Celestún coastal lagoon (Fig. 1).
These studies have advanced the hydrologic and hydrochemical understanding of the Yucatan Peninsula. However, chemical data are needed from the RC in order to increase our understanding of the spatial and temporal variations in water chemical composition. The RC offers a myriad of research opportunities, because it is located in an area influenced by local factors such as human land use, as well as regional factors such as subterranean flow. The present study's objectives were to spatially and temporally quantify the physical and chemical characteristics of water in representative cenotes along the $\mathrm{RC}$, to identify similarities among the cenotes based on chemical composition in order to obtain a hydrochemical regionalization of the area, and to establish characteristic values for these regions.

\section{Study Area}

The RC area covers the northwest portion of the Yucatan Peninsula $\left(88^{\circ} 30^{\prime}\right.$ and $90^{\circ} 30^{\prime} \mathrm{W}, 20^{\circ} 00^{\prime}$ and $21^{\circ} 30^{\prime} \mathrm{N}$ ) (Steinich et al., 1996). The width of the RC is approximately $12 \mathrm{~km}$, and extends from the coastal lagoon of Celestún in the west to the Bocas de Dzilam lagoon in the east, both in Yucatán state (Fig. 1). 
Table 1. Names and locations of the twenty-two sampled cenotes. The distance from shoreline is along the path of flow, not the shortest line.

\begin{tabular}{rllccc}
\hline ID & \multicolumn{1}{c}{ Name } & Municipality & Latitude, N $\left(^{\circ}\right)$ & Longitude, W $\left(^{\circ}\right)$ & Distance to Shoreline, km \\
\hline 1 & Sabtún & Celestún & 20.850260 & 90.235590 & 13.45 \\
2 & Xelactún & Kinchil & 20.889640 & 90.081060 & 26.94 \\
3 & Chunchucmil & Celestún & 20.813056 & 90.196667 & 19.29 \\
4 & Chen ha & Kopomá & 20.689480 & 89.875890 & 59.72 \\
5 & Yax ha & Abalá & 20.672640 & 89.774157 & 68.13 \\
6 & Kankirixche & Abalá & 20.637230 & 89.632980 & 82.22 \\
7 & Sabak ja & Sacalum & 20.580490 & 89.588200 & 93.10 \\
8 & Nayah & Tecoh & 20.646510 & 89.404670 & 108.12 \\
9 & X-pakay & Tekit & 20.539150 & 89.365040 & 115.82 \\
10 & Uitzan & Tekit & 20.580690 & 89.342140 & 116.67 \\
11 & Chonquilá & Tecoh & 20.637760 & 89.344290 & 118.23 \\
12 & Lum há & Tekit & 20.602230 & 89.260180 & 121.69 \\
13 & Uaymil & Homún & 20.681910 & 89.253120 & 106.74 \\
14 & Ixinha & Huhí & 20.630350 & 89.110750 & 110.29 \\
15 & X-colac & Izamal & 20.909770 & 88.866290 & 61.91 \\
16 & Hotzó & Izamal & 20.904070 & 88.861730 & 62.36 \\
17 & Chen Vázquez & Buctzotz & 21.148380 & 88.657850 & 41.56 \\
18 & San Pedro & Buctzotz & 21.189070 & 88.659620 & 36.16 \\
19 & Itzincab & Buctzotz & 21.227510 & 88.679290 & 25.95 \\
20 & Dzonot sábila & Buctzotz & 21.310510 & 88.747790 & 12.98 \\
21 & X-kay & Buctzotz & 21.306790 & 88.788100 & 13.14 \\
22 & Dzonot Trejo & Dzilam González & 21.312060 & 88.667860 & 16.41 \\
\hline
\end{tabular}

The calcareous plain of the peninsula is formed of Quaternary (Holocene-Pleistocene) sediments in the form of limestone rock of the Paleogene Carrillo Puerto formation. Surface topography is flat with very smooth slope (Perry et al., 1995). Solubility of limestone is produced by carbon dioxide originated in the soil-plant system infiltrated by rainfall (Gaona-Vizcayno et al., 1980). Secondary porosity, fractures, underground channels, and caverns are the main sources of the aquifer permeability (Steinich et al., 1996).

The peninsula's aquifer is unconfined, with the exception of a slight hydrogeological confinement created by a thin $(0.5$ to $1.4 \mathrm{~m})$ caliche layer along the coastal margin (Perry et al., 1989). The static level varies from 1.0 meters above sea level (masl) at the coast to up to 10.0 masl to the south of the RC (INEGI, 2002). The potentiometric level varies from less than 1.0 masl near the coast to 5.0 masl in the southeast part of the RC (SARH, 1989).

Habitat biodiversity in the study region includes marine, coastal, and inland areas. Marine areas contain features such as the continental platform, extensive seagrass meadows, and intertidal zones. The coastal area includes mangrove wetlands, coastal dunes, and seasonally flooded forest. Inland areas are characterized by thorny dry forest, semi-evergreen tropical forest, and dry tropical forest. Soil types in the area include regosols associated with sand barrier islands and beaches, solonchaks and histosols in the mangrove wetlands, and litosols and rendzins in the inland forests (Batllori-Sampedro et al., 2006).

Climate zones in the Yucatan include the driest of the arid and semiarid classes, and cover a spectrum from the driest of the subhumid hot to very hot classes. Three seasons occur in the region, a dry season with high temperatures and low rainfall (March to May), a rainy season with frequent rainfall (June to October), and a coldfronts season with winter storms and occasional rainfall (November to February) (Schmitter-Soto et al., 2002).

The cenotes included in the study were open air, with the exception of two semi-open ones (see classification proposed by Duch, 1991). Cenotes in the area are used to provide water for livestock, crop irrigation, and human use.

\section{Methods}

Based on the cenote inventory of the Yucatan State Secretariat of Ecology (SECOL, 1999), a preliminary selection of fifty-two cenotes within the RC was made. Field data on accessibility and depth were collected. From a selection of about thirty cenotes reasonably well distributed in the study area, twenty-nine were found to have a minimum water depth of $11 \mathrm{~m}$. Seven proved to be inaccessible, giving a final sample of twenty-two (Fig. 1). The names of the cenotes, their municipalities, geographic coordinates, and their distances from the shoreline are given in Table 1. 
Table 2. Chemical methods used in the study.

\begin{tabular}{ll}
\hline Analysis & \multicolumn{1}{c}{ Analytical Methods } \\
\hline Alkalinity & Titration \\
Calcium & EDTA titrimetric \\
Magnesium & $\begin{array}{c}\text { Calculation (difference between hardness } \\
\text { and calcium as calcium carbonate) }\end{array}$ \\
Chloride & Argentometric \\
Sulfate & Turbidimetric \\
Sodium & Atomic absorption spectrometric \\
Potassium & Atomic absorption spectrometric \\
Nitrate & Ultraviolet spectrophotometric screening \\
\hline
\end{tabular}

A total of 198 water samples were collected from the twenty-two cenotes. Water samples were taken at three water depths during the three seasons, dry, rainy, and coldfronts. In situ measurements of water temperature, $\mathrm{pH}$, electrical conductivity and dissolved oxygen were obtained using a multiparameter probe (Hydrolab G-Quanta). Water samples were taken at depths of $0.5,5.5$, and $10.5 \mathrm{~m}$ using $1.0 \mathrm{~L}$ and $0.25 \mathrm{~L}$ plastic bottles and were kept cold during transport to the laboratory for major ion and other chemical analyses. Concentrations of major ions and alkalinity were determined in accordance with standard methods for each analyte (APHA-AWWA-WPCF, 2005) (Table 2). Quality of the results was established by analysis at least three times for each sample for titration, titrimetric, and argentometric methods, and by calibration with standards and analysis of reagent blanks for turbidimetric, atomic-absorption spectrometric, and ultraviolet spectrophotometric screening methods. Charge-balance errors were as total cations minus total anions divided by total ions, all in meq $\mathrm{L}^{-1}$, times 100 (Deutsch, 1997). A total of $87 \%$ of the samples had cation/anion balance of $\pm 5 \%$, while the remaining $13 \%$ were between \pm 5 and $\pm 10 \%$.

To visualize and explore the spatial and temporal behavior of the chemical and physical characteristics, a set of plots were created (Figs. 2-4). In these plots the numbers on the abscissa identify the cenotes according to their location within the RC from Celestún to Dzilam de Bravo (Fig. 1). The trend lines were generated using a locally weighted regression method (LOWESS) that filters the dispersion of each variable (Di Rienzo et al., 2008).

An exploratory analysis of normality was done to decide which statistical technique to apply. The data did not fit a normal distribution, and they were consequently analyzed with a non-parametric Kruskal-Wallis test to identify any significant differences among depths and seasons. Considering the univariate exploratory graphic analysis, the limited data provided by the non-parametric univariate statistical analysis, and the depth and season data, it was decided to regionalize the cenotes using spatial structural characteristics to provide a more informative and relevant result. Three groups were proposed based on the major ion concentrations and the variability of these parameters over season and space. These groups were evaluated and tested with a sequence of multivariate analyses, Principal Component Analysis (PCA), Permutational Multivariate Analysis of Variance (PERMANOVA), and Canonical Analysis of Principal Coordinates (CAP), based on ten hydrochemical variables (conductivity, $\mathrm{pH}, \mathrm{K}^{+}, \mathrm{Na}^{+}, \mathrm{Mg}^{2+}, \mathrm{Ca}^{2+}, \mathrm{HCO}_{3}^{-}$, $\mathrm{SO}_{4}^{2-}, \mathrm{Cl}^{-}, \mathrm{NO}_{3}^{-}$) and distance from each cenote to the shoreline along the groundwater flow.
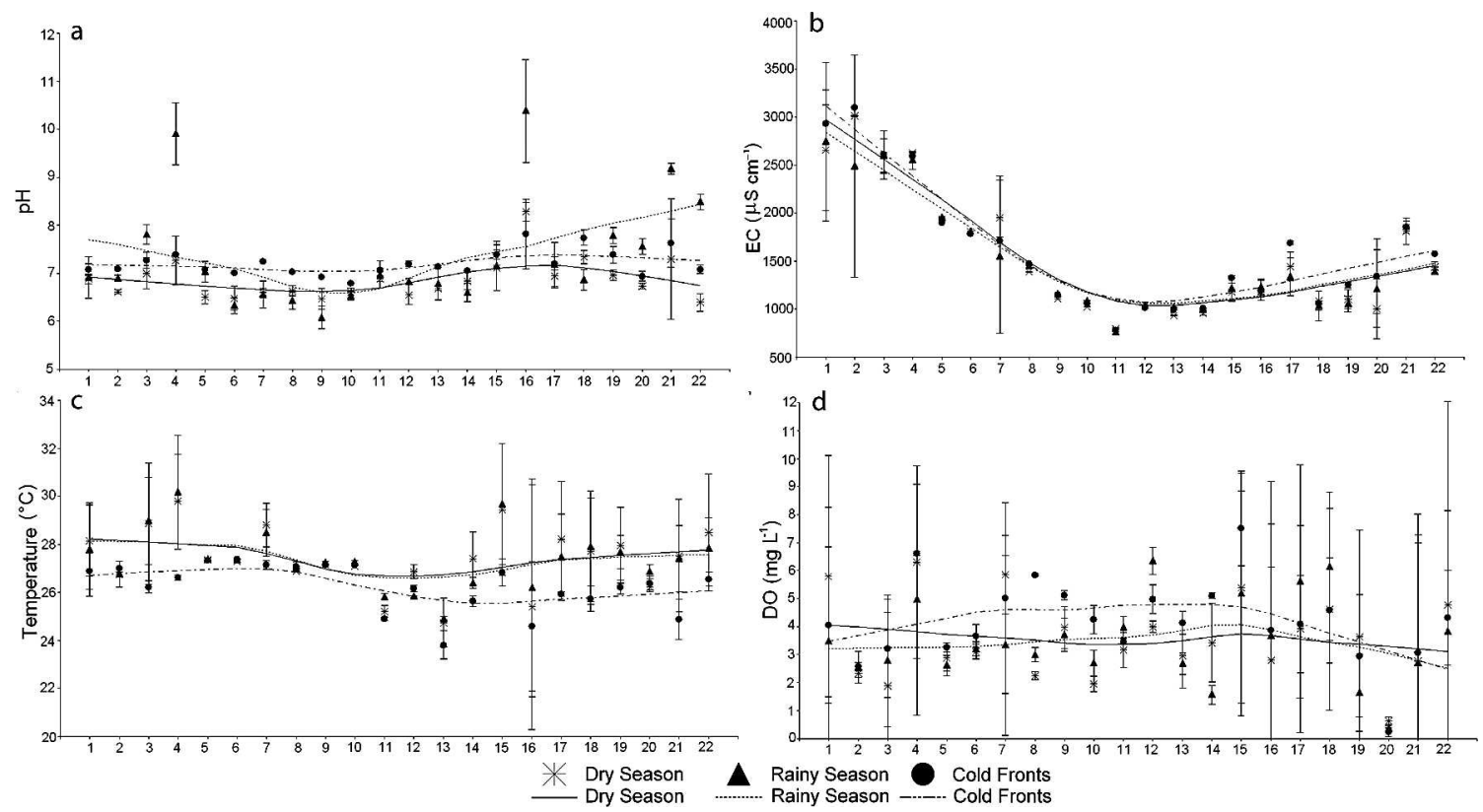

Figure 2. Spatial and temporal patterns from field variables averaged for three depths and measured at the twenty-two cenotes. EC is electrical conductivity and DO is dissolved oxygen. 


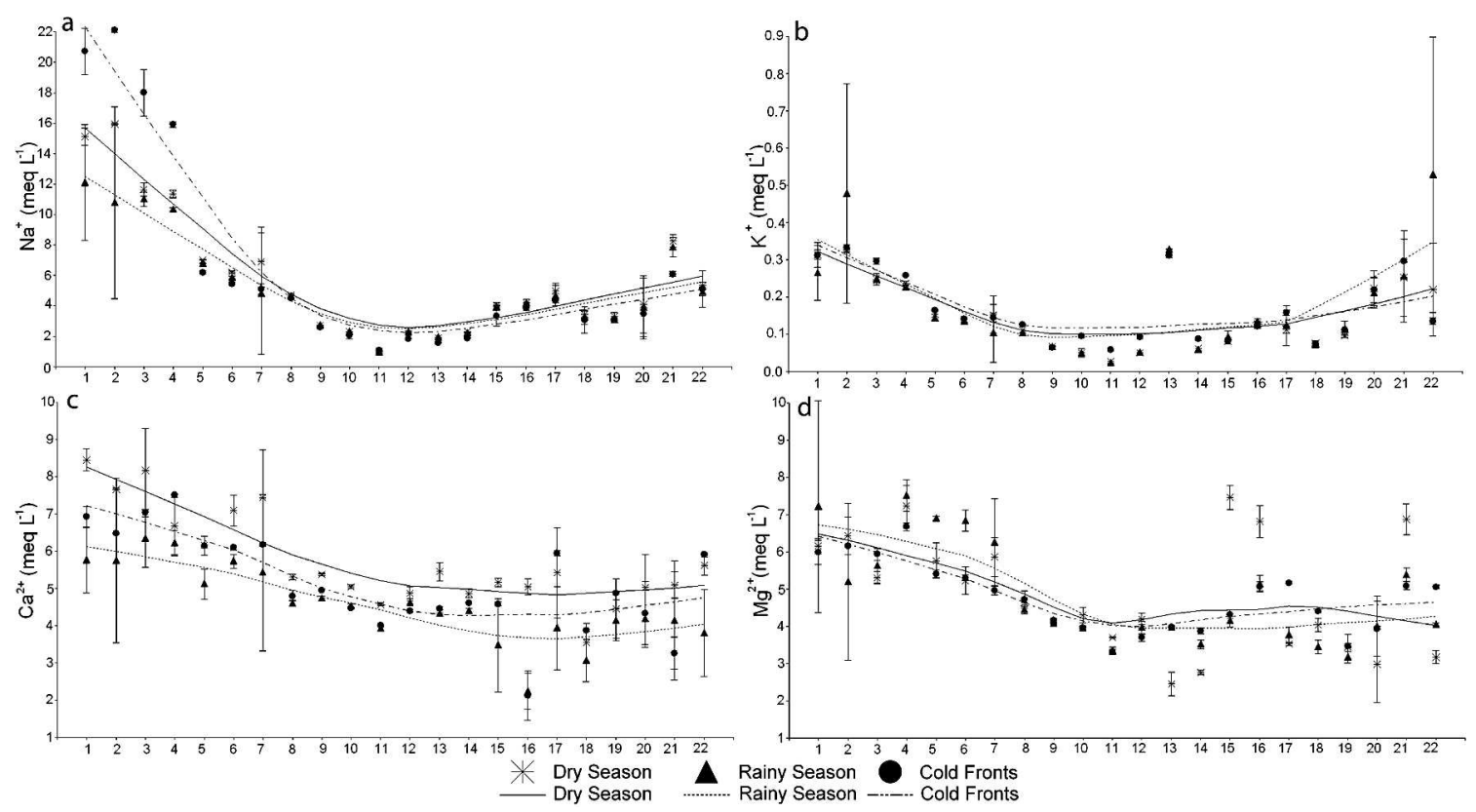

Figure 3. Spatial and temporal patterns in cation concentrations averaged for three depths and measured at the twentytwo cenotes.

PCA was applied to identify structural patterns in the multivariate data matrix of eleven variables measured at the twenty-two cenotes grouped into three regions (west, center, and east) in three seasons, treating the measurements at different depths as repetitions. The PCA was based on a correlation matrix of logarithm-transformed (base 10) data normalized to eliminate the influence of differences between measurement units. This technique aims to reduce data dimensionality and to search for linear relationships among the original variables through the creation of new, independent variables that explain the maximum possible variation in the original data.

The general hypothesis of no differences between seasons and cenote groups was tested using PERMANOVA. This simultaneously falsifies the response of the eleven measured variables versus the factors season and

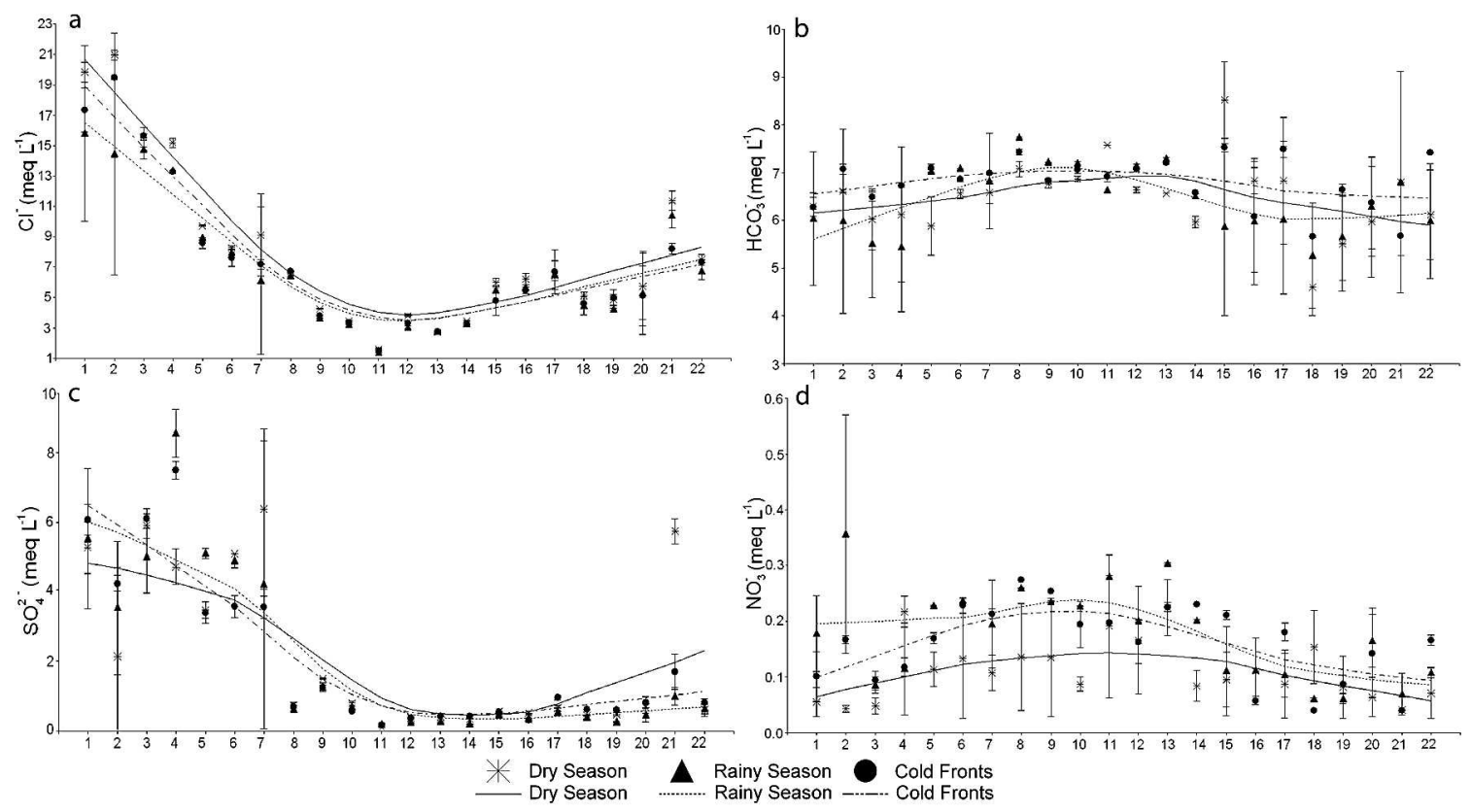

Figure 4. Spatial and temporal patterns of anion concentrations averaged for three depths and measured at the twentytwo cenotes. 


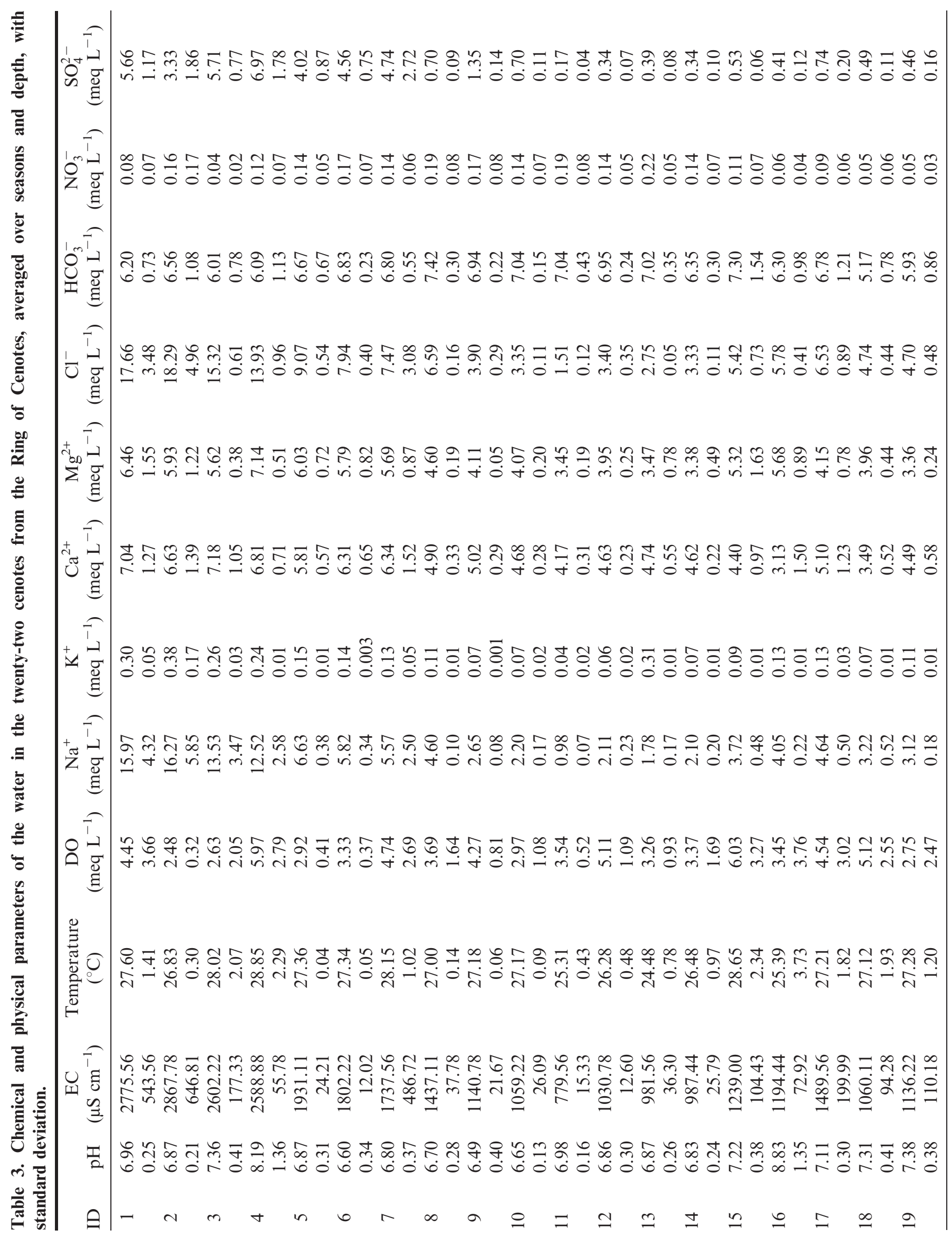




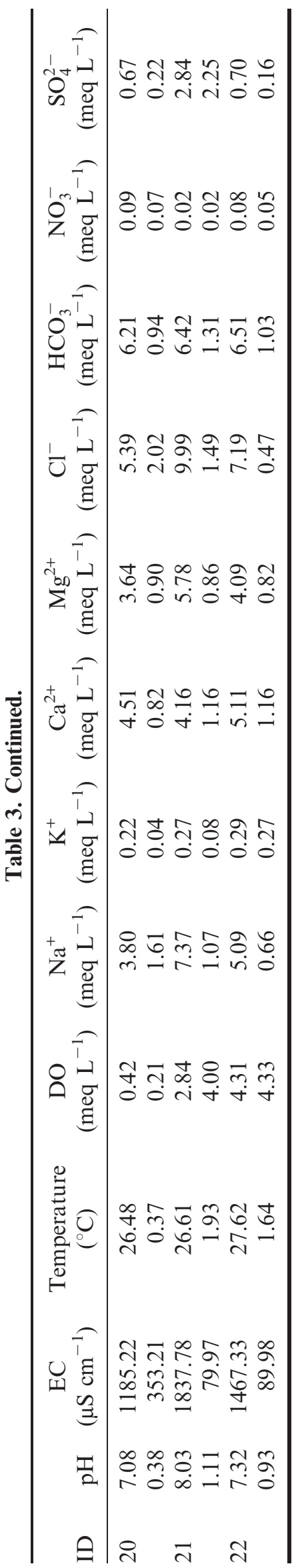

cenote group in a multivariate analysis of variance using a two-factor (season and group) and a-posteriori structured design over the Euclidean distances, applying permutational methods.

Finally, a CAP was done to maximize separation between groups. The first objective of the CAP was to identify axes whose direction was fundamentally different from the maximum variation identified with the PCA and that maximize the separation of the groups proposed and falsified with the PERMANOVA. The second objective was to diagnose and cross-validate the a priori assignment of the cenotes to the three groups to determine which groups were more different than others. This analytical sequence helped identify similarity between the chemical characteristics of the different cenotes and then propose chemical values representative of each region.

\section{RESULTS}

Chemical and physicochemical water parameters obtained for each cenote are shown in Table 3. The upper value in each cell is the mean and the lower value is the standard deviation.

\section{Field VARIABLES}

Annual average $\mathrm{pH}$ was $7.15( \pm 0.78)$, with a minimum of 5.81 (cenote 9) and a maximum of 11.06 (cenote 16), both recorded in the rainy season. High $\mathrm{pH}$ values are likely a result of organic matter derived from cattle farming, washed by rain into the cenotes. The KruskalWallis test showed significant differences $(p<0.0001)$ between the medians for seasons but not for depths. Values for $\mathrm{pH}$ increased from the $\mathrm{RC}$ center (cenote 9) towards its two extremes, with the highest increase towards the east. In the center, pH values were slightly acid (5.81-6.9) (Fig. 2a).

Annual average electrical conductivity was 1560.52 $\mu \mathrm{S} \mathrm{cm}^{-1}( \pm 659.64)$, with a minimum of $763 \mu \mathrm{S} \mathrm{cm}^{-1}$ (recorded in cenote 11 in the center) and a maximum of $3250 \mu \mathrm{S} \mathrm{cm}^{-1}$ (recorded in cenote 1 in the west near the coast), both during the rainy season. Overall, EC values increased from the center outwards during all three seasons as the result of ion incorporation from water-rock interaction and sea-water encroachment. However, the increase in EC towards the west $\left(2775 \mu \mathrm{S} \mathrm{cm}^{-1}\right.$ at cenote 1$)$ was notably higher than towards the east $\left(1467 \mu \mathrm{S} \mathrm{cm}^{-1}\right.$ at cenote 22). Both cenotes are located approximately $18 \mathrm{~km}$ from the coast. During the cold fronts season, EC increased at both ends of the ring, in cenotes 1 through 4 in the west and in cenotes 20 to 22 in the east (Fig. 2b). In each of the two arms of the RC (considered separately), distance from the coast was correlated with EC. Terrain slope is steeper in the east and gentle on the west, resulting in more saline intrusion in the west compared to the east.

Average annual water temperature was $27.02{ }^{\circ} \mathrm{C}( \pm$ 1.74) with a minimum of $22.2{ }^{\circ} \mathrm{C}$ (cenote 16 at $10.5 \mathrm{~m}$ 
depth) and a maximum of $32.2{ }^{\circ} \mathrm{C}$ (cenote 15 at $0.5 \mathrm{~m}$ depth), both recorded during the dry season. Differences were not significant among seasons and depths. Spatially, the cenotes in the RC's center exhibited less temperature variability than cenotes at its edges (Fig. 2c).

For all cenotes in the RC, annual average dissolved oxygen (DO) content was $3.73 \mathrm{mg} \mathrm{L}^{-1}$ ( \pm 2.57 ), with a minimum average of $0.96 \mathrm{mg} \mathrm{L}^{-1}$ at a depth of $10.5 \mathrm{~m}$ (cenote 3) and a maximum of $13.16 \mathrm{mg} \mathrm{L}^{-1}$ at $0.5 \mathrm{~m}$ (cenote 22). Median values for DO were significantly different among seasons $(\mathrm{p}=0.0325)$ and depth $(\mathrm{p}<0.0001)$. In general, DO decreased with depth. The DO concentration in the water column was least variable during the coldfronts season, with the highest concentrations located at the center of the RC (Fig. 2d).

\section{LABORATORY VARIABLES Cations}

Average annual $\mathrm{Na}^{+}$content was $5.81 \mathrm{meq} \mathrm{L}^{-1}( \pm 4.84)$ with a minimum of 0.88 meq $\mathrm{L}^{-1}$ (cenote 11) in the rainy season and a maximum of $22.45 \mathrm{meq} \mathrm{L}^{-1}$ (cenote 1 ) in the cold fronts season. No differences were observed between seasons or depths. Concentrations tended to increase with depth, mainly during the dry and rainy seasons. Cenotes with the most constant $\mathrm{Na}^{+}$concentration were located in the RC's center and east. During all three seasons, concentrations increased from the center towards the extremes, with the highest increase observed over the approximately $10 \mathrm{~km}$ distance between cenotes 5 (6.6 meq $\left.\mathrm{L}^{-1}\right)$ and $4\left(12.5 \mathrm{meq} \mathrm{L}^{-1}\right)$ in the west. $\mathrm{Na}^{+}$ concentration was directly related to electrical conductivity. Generally, the lowest concentrations were recorded during the rainy season (Fig. 3a).

Annual average $\mathrm{K}^{+}$levels were $0.16 \mathrm{meq} \mathrm{L}^{-1}( \pm 0.12)$, with a minimum of $0.02 \mathrm{meq} \mathrm{L}^{-1}$ (cenote 11) and a maximum of $0.81 \mathrm{meq} \mathrm{L}^{-1}$ (cenote 2 ), both recorded during the rainy season. No differences were observed between seasons or depths. Overall $\mathrm{K}^{+}$levels were most variable during the rainy season and least variable during the cold fronts season. In all three seasons, $\mathrm{K}^{+}$concentrations decreased with depth. Concentrations were lowest in the RC's center (cenote 11) and increased towards the coasts. The one exception was cenote 13, where concentrations surpassed 0.3 meq $\mathrm{L}^{-1}$ in all three seasons (Fig. 3b).

For $\mathrm{Ca}^{2+}$, annual average concentration was $5.15 \mathrm{meq} \mathrm{L}^{-1}( \pm 1.40)$, with a minimum value of $1.67 \mathrm{meq} \mathrm{L}^{-1}$ (cenote 16) during the rainy season and a maximum of $9.17 \mathrm{meq} \mathrm{L}^{-1}$ (cenote 3) during the dry season. Differences were present between seasons $(p<0.0001)$ and between depths $(p<0.0354)$. The highest variability was observed during the dry season and the lowest during the cold-fronts season. $\mathrm{Ca}^{2+}$ concentration also increased with depth, particularly during the dry and rainy seasons and on both sides of the RC. Concentration variation with depth in the water column was least in cenotes in the center. Overall, concentrations were highest in the cenotes to the west compared to those in the center and east (Fig. 3c).

Average annual $\mathrm{Mg}^{2+}$ concentration was $4.80 \mathrm{meq} \mathrm{L}^{-1}( \pm$ 1.40 ) with a minimum of $1.95 \mathrm{meq} \mathrm{L}^{-1}$ (cenote 20) during the dry season and a maximum of $8.90 \mathrm{meq} \mathrm{L}^{-1}$ (cenote 1) during the rainy season. Variability was highest during the dry season and lowest during the cold-fronts season. Most of the studied cenotes exhibited an increase in $\mathrm{Mg}^{2+}$ concentrations with depth, except during the cold-fronts season. No differences were observed between seasons or depths. Spatially, concentrations were highest (average $6.09 \mathrm{meq} \mathrm{L^{-1 }}$ ) in the west (cenotes 1 to 7 ) compared to all the other cenotes (average $4.2 \mathrm{meq} \mathrm{L}^{-1}$ ). The lowest variability in concentrations was recorded in cenotes in the center (Fig. 3d).

\section{Anions}

Average annual $\mathrm{Cl}^{-}$concentration was $7.46 \mathrm{meq} \mathrm{L}^{-1}$ ( \pm 4.9) with a minimum of $1.37 \mathrm{meq} \mathrm{L}^{-1}$ (cenote 11) during the rainy season and a maximum of $21.15 \mathrm{meq} \mathrm{L}^{-1}$ (cenote 2) during the dry season. No differences were observed between seasons or depths. During the dry and rainy seasons, concentrations increased with depth. Watercolumn $\mathrm{Cl}^{-}$concentration variability with depth was highest in cenotes 1,2 and 7 , in the west. In all three seasons, $\mathrm{Cl}^{-}$concentrations were lowest in the center (cenote 11) and increased to the west and east. The increase was greatest towards the west, with an increase from $9.07 \mathrm{meq} \mathrm{L}^{-1}$ (cenote 5) to $13.93 \mathrm{meq} \mathrm{L}^{-1}$ (cenote 4) over an approximately $10 \mathrm{~km}$ distance; this is similar to the behavior of electrical conductivity and sodium (Fig. 4a).

Average annual $\mathrm{HCO}_{3}^{-}$concentration was $6.57 \mathrm{meq} \mathrm{L}{ }^{-1}$ ( \pm 0.93 ) with a minimum of $3.76 \mathrm{meq} \mathrm{L}^{-1}$ (cenote 2) during the rainy season and a maximum of 9.36 meq $\mathrm{L}^{-1}$ (cenote 15) during the dry season. Concentrations were most variable during the rainy season and least variable in the cold-fronts season. Differences were observed among seasons $(p=0.022)$ and among depths $(p=0.0001)$. The lowest variability in water-column $\mathrm{HCO}_{3}^{-}$concentrations was recorded in the central cenotes. Concentrations generally increased with depth. In all three seasons, concentrations were lower to the west and east compared to higher levels in the center (Fig. 4b).

Average annual $\mathrm{SO}_{4}^{2-}$ concentration was $2.08 \mathrm{meq} \mathrm{L} \mathrm{L}^{-1}$ ( \pm 2.36) with a minimum of 0.12 meq $\mathrm{L}^{-1}$ (cenote 11) during the dry season and a maximum of $9.27 \mathrm{meq} \mathrm{L}^{-1}$ (cenote 7) during the rainy season. No differences were observed between seasons or depths. Variability was lowest during the cold fronts season and highest during the rainy season. Concentration was positively related to depth. The highest water-column concentration variability was recorded in cenotes in the west. In all three seasons, $\mathrm{SO}_{4}^{2-}$ concentrations increased from the center towards the west; a notable increase was recorded over the approximately $23 \mathrm{~km}$ distance between cenotes $9\left(1.35 \mathrm{meq} \mathrm{L}^{-1}\right)$ and 7 (4.74 meq L ${ }^{-1}$ ) (Fig. 4c).

Journal of Cave and Karst Studies, April 2012•97 
Table 4. Percentage of variation explained, plus coefficients, for the linear combination of eleven variables making up the first two principal components (PC) for the twenty-two cenotes sampled during the dry, rainy, and cold-fronts seasons.

\begin{tabular}{lrr}
\hline Variable & $\mathrm{PC}^{\mathrm{a}}$ & \multicolumn{1}{c}{$\mathrm{PC}^{\mathrm{a}}$} \\
\hline $\mathrm{pH}$ & 0.066 & $\mathbf{0 . 4 0 6}$ \\
Conductivity & $\mathbf{0 . 4 1 1}$ & -0.094 \\
$\mathrm{Na}^{+}$ & $\mathbf{0 . 4 1 5}$ & 0.022 \\
$\mathrm{~K}^{+}$ & 0.310 & 0.186 \\
$\mathrm{Ca}^{2+}$ & 0.258 & $\mathbf{- 0 . 4 1 9}$ \\
$\mathrm{Mg}^{2+}$ & 0.324 & -0.169 \\
$\mathrm{Cl}^{-}$ & $\mathbf{0 . 4 1 6}$ & 0.029 \\
$\mathrm{HCO}_{3}^{-}$ & -0.025 & $\mathbf{- 0 . 5 1 8}$ \\
$\mathrm{SO}_{4}^{2-}$ & $\mathbf{0 . 3 7 1}$ & -0.154 \\
$\mathrm{NO}_{3}^{-}$ & -0.116 & -0.377 \\
Distance to shoreline & -0.248 & $\mathbf{- 0 . 3 9 0}$ \\
\hline
\end{tabular}

${ }^{a}$ Bold numbers are coefficients for the most influential variables on each Principal Component.

Average annual $\mathrm{NO}_{3}^{-}$concentration was $0.12 \mathrm{meq} \mathrm{L}^{-1}$ $\left( \pm 0.08\right.$ ), with a minimum of $0.009 \mathrm{meq}^{-1}$ (minimum detectable level) during the dry and cold-fronts seasons and a maximum of 0.56 meq $\mathrm{L}^{-1}$ (cenote 2) during the rainy season. Differences were observed between seasons $(p<0.0001)$, but not between depths. Concentrations were highly variable during all three seasons and in all the studied cenotes, although the highest overall concentrations were recorded in the rainy season. During all three seasons, $\mathrm{NO}_{3}^{-}$concentrations were highest in cenotes in the center compared to those to the west and east (Fig. 4d).

\section{Regionalization of the Ring of Cenotes}

Three groups of cenotes were established using the ten hydrochemical variables and the distance to the shoreline along the groundwater flow directions. Group 1 includes cenotes on the RC's west side, cenotes 1 to 7 . Group 2 encompasses cenotes 8 to 14 in the center, and Group 3 includes cenotes 15 to 22 on the east side (Fig. 1).

The first two principal components from the Principal Component Analysis explained $69.3 \%$ of the total variation based on the maximum variation from eleven original variables (Table 4). The first component (PC1) explained $50.1 \%$ of the variation; the maximum variation in $\mathrm{PC} 1$ separated Group 1 from the others as a function of increases in electrical conductivity and the $\mathrm{Na}^{+}, \mathrm{Cl}^{-}$and $\mathrm{SO}_{4}^{2-}$ ions. The second component (PC2) explained 19.2\% of the variation; the maximum variation of $\mathrm{PC} 2$ separated Groups 2 and 3, mainly in response to the $\mathrm{Ca}^{2+}$, and $\mathrm{HCO}_{3}^{-}$ions and the $\mathrm{pH}$ and distance-to-shoreline variables. Both principal components showed high variability within Group 3 (Fig. 5).

The Permutational Multivariate Analysis of Variance quantified differences by season and group, as well as the season-group interaction factor $(\mathrm{S} \times \mathrm{G})$. There were clear differences due to the main-factors effect, although the

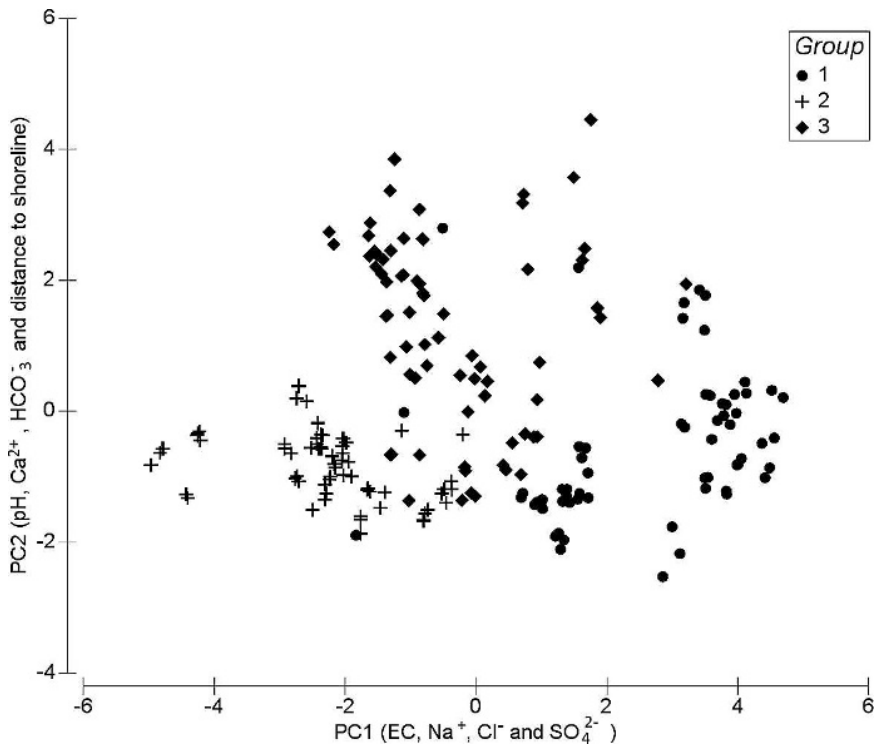

Figure 5. Multivariate ordination from Principal Components Analysis (labels on the principal axes PC1 and PC2 correspond to the most influential variables).

interaction term between main factors was also significant, meaning the effects of the main factors were not independent (Table 5).

The a posteriori paired pseudo-t test allowed us to identify the interaction source. When the "group" effect was fixed, the pattern of differences between seasons changed depending on the group observed, but when the "season" effect was fixed, the pattern of differences between groups did not change (Table 6). Therefore, the difference from the interaction term was caused by the dependence of season on the group observed $(p<0.01)$. In other words, season has an effect only on a particular group of cenotes, but the spatial pattern of group differences is consistent temporally, based on the hydrochemical characteristics (Table 6).

The Canonical Analysis of Principal Coordinates also showed the effect of the grouping of the cenotes based on the hydrochemical data (Fig. 6). Cross-validation analysis of the classification of cenotes into groups corroborated that $96.8 \%$ of the cenotes in Group 1 were correctly allocated, $100 \%$ in Group 2, and $91.7 \%$ in Group 3.

Once regionalized, the average of the hydrochemical variables values ( \pm standard deviation) were calculated for the three regions: Region 1, Region 2, Region 3 (Fig. 1, Table 7).

\section{Discussion}

\section{SPATIAL TRENDS}

The large number of cenotes and special hydrogeological properties make the $\mathrm{RC}$ a unique region for the study of groundwater. The studied chemical and physical variables exhibited patterns and specific behavior along the RC. 
Table 5. Permutational Multivariate Analysis of Variance results of significant differences in water properties for a structured two-factor crossed design of main factor season and group of cenotes and the interaction term season $\times$ group.

\begin{tabular}{lccccc}
\hline Variation Source & $\mathrm{df}^{\mathrm{a}}$ & $\mathrm{SS}^{\mathrm{b}}$ & $\mathrm{MS}^{\mathrm{c}}$ & $p$ seudo- $\mathrm{F}^{\mathrm{d}}$ & $p(\mathrm{perm})^{\mathrm{e}}$ \\
\hline Season & 2 & 80.433 & 40.216 & 6.6664 & $\mathbf{0 . 0 0 0 1}$ \\
Group & 2 & 904.6 & 452.3 & 74.975 & $\mathbf{0 . 0 0 0 1}$ \\
Season $\times$ Group & 4 & 40.439 & 10.11 & 1.6758 & $\mathbf{0 . 0 2 9 8}$ \\
\hline
\end{tabular}

${ }^{\mathrm{a}} \mathrm{df}=$ Degrees of freedom

${ }^{\mathrm{b}} \mathrm{SS}=$ Sum of Squares.

${ }^{\mathrm{c}} \mathrm{MS}=$ Sum of Mean squares.

${ }^{\mathrm{d}} p$ seudo-F $=$ Test statistic based on distance measure.

${ }^{\mathrm{e}} p($ perm $)=$ Probability based on permutations.

Bold figures are statistically significant to $p<0.05$.

The variables of $\mathrm{pH}$ and temperature are distinctly different in the center, where $\mathrm{pH}$ was moderately acidic (5.81 to 6.90) and temperature remained almost constant $\left(26.27{ }^{\circ} \mathrm{C} \pm 1.08\right)$ during all three seasons. This suggests that this portion of the RC functions as a hydrological recharge zone that receives water mainly from direct filtration of rainfall through the permeable karst formation. This agrees with the fact that aquifer recharge zones can exhibit temperature effects that facilitate greater limestone dissolution (Custodio and Llamas, 1983, p. 1017), and the low $\mathrm{pH}$ values result from the direct recharge by rain water infiltration, which has a mean $\mathrm{pH}$ value of 6 in the groundwater of Yucatán state (Cabrera et al., 1996).

Electrical conductivity, $\mathrm{Na}^{+}$and $\mathrm{Cl}^{-}$concentrations had similar spatial patterns, with considerable increases in the west. All three increased notably from cenote 4 to cenote 1 . Average values at these three cenotes $(\mathrm{EC}=$

Table 6. Pair-wise comparisons for the interaction term season $\times$ group, when level of group (first column) and season (third column) is fixed (bold figures are statistically significant at $p<0.05$ ).

\begin{tabular}{lccc}
\hline Group 1 & $p$ (perm) & Season D & $p$ (perm) \\
\hline D-R & $\mathbf{0 . 0 0 2}$ & $1-2$ & $\mathbf{0 . 0 0 1}$ \\
D-CF & $\mathbf{0 . 0 0 9}$ & $1-3$ & $\mathbf{0 . 0 0 1}$ \\
R-CF & 0.089 & $2-3$ & $\mathbf{0 . 0 0 1}$ \\
\hline Group 2 & \multicolumn{3}{|}{ Season R } \\
\hline D-R & $\mathbf{0 . 0 1 0}$ & $1-2$ & $\mathbf{0 . 0 0 1}$ \\
D-CF & $\mathbf{0 . 0 0 2}$ & $1-3$ & $\mathbf{0 . 0 0 1}$ \\
R-CF & 0.058 & $2-3$ & $\mathbf{0 . 0 0 1}$ \\
\hline Group 3 & & Season CF \\
\hline D-R & $\mathbf{0 . 0 0 1}$ & $1-2$ \\
D-CF & 0.251 & $1-3$ & $\mathbf{0 . 0 0 1}$ \\
R-CF & $\mathbf{0 . 0 1 2}$ & $2-3$ & $\mathbf{0 . 0 0 1}$ \\
\hline D - dry, R & CF
\end{tabular}

$\mathrm{D}=$ dry, $\mathrm{R}=$ rainy, $\mathrm{CF}=$ cold-fronts season.

Numbers 1, 2 and 3 refer to cenote group.

Bold figures are statistically significant at $p<0.05$.
$2,708 \mu \mathrm{S} \mathrm{cm}{ }^{-1} ; \quad \mathrm{Na}^{+}=14.58 \mathrm{meq} \mathrm{L}^{-1} ; \mathrm{Cl}^{-}=$ $16.30 \mathrm{meq} \mathrm{L}^{-1}$ ) were higher than normal freshwater values for these variables, which are $\mathrm{EC}=100$ to $2,000 \mu \mathrm{S} \mathrm{cm} \mathrm{cm}^{-1}$ (Donado, 1999), $\mathrm{Na}^{+}=4.35$ to $6.52 \mathrm{meq} \mathrm{L}^{-1}$ (Custodio and Llamas, 1976, p. 203), and $\mathrm{Cl}^{-}=0.85-4.22 \mathrm{meq} \mathrm{L}^{-1}$ (Melloul and Goldenberg, 1998). The cause of these higher values, with $\mathrm{Cl}^{-}>8.5 \mathrm{meq} \mathrm{L}^{-1}$ up to $55 \mathrm{~km}$ inland from the coast at cenote 4 , is probably seawater encroachment (Escolero et al., 2005).

$\mathrm{K}^{+}$concentration tended to increase from the center towards the coast. $\mathrm{K}^{+}$concentrations in the aquifer are mainly due to agricultural discharge and seawater encroachment (Pacheco et al., 2001). Variability was highest during the rainy season as a result of rainfall washing contaminants into the groundwater. Most of the groundwater in Yucatán state contains $\mathrm{K}^{+}$levels between $1 \mathrm{ppm}$ $\left(0.0256 \mathrm{meq} \mathrm{L}^{-1}\right)$ and $5 \mathrm{ppm}\left(0.128 \mathrm{meq}^{-1}\right)$, and almost always below 10 ppm $\left(0.256 \mathrm{meq} \mathrm{L}^{-1}\right)$ (Cabrera, 1986). Cenote 13 had a higher $\mathrm{K}^{+}$concentration $\left(0.3 \mathrm{meq} \mathrm{L}^{-1}\right)$ in all seasons probably due to the use of fertilizers in the

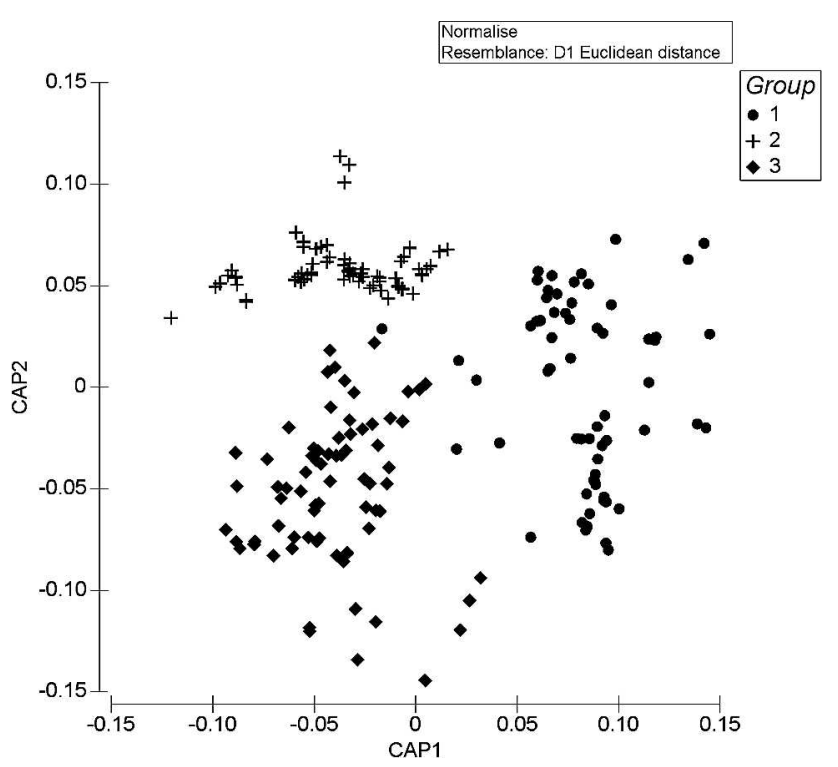

Figure 6. Canonical Analysis of Principal Coordinates of the groups based on hydrochemical variables.

Journal of Cave and Karst Studies, April 2012•99 
Table 7. Average values over all samples from the cenotes from each group.

\begin{tabular}{|c|c|c|c|}
\hline Variable & Group $1 \bullet$ & Group $2+$ & Group 3 • \\
\hline $\mathrm{pH}$ & $7.09 \pm 0.75$ & $6.77 \pm 0.30$ & $7.53 \pm 0.92$ \\
\hline Conductivity & $2329 \pm 577$ & $1059 \pm 188$ & $1326 \pm 287$ \\
\hline $\mathrm{Na}^{+}\left(\right.$meq L $\left.{ }^{-1}\right)$ & $10.90 \pm 5.47$ & $2.35 \pm 1.05$ & $4.38 \pm 1.50$ \\
\hline $\mathrm{K}^{+}(\mathrm{meq} \mathrm{L}-1)$ & $0.23 \pm 0.11$ & $0.10 \pm 0.09$ & $0.16 \pm 0.12$ \\
\hline $\mathrm{Ca}^{2+}\left(\right.$ meq L L $\left.{ }^{-1}\right)$ & $6.59 \pm 1.12$ & $4.68 \pm 0.40$ & $4.30 \pm 1.19$ \\
\hline $\mathrm{Mg}^{2+}\left(\right.$ meq L $\left.^{-1}\right)$ & $6.09 \pm 1.03$ & $3.86 \pm 0.56$ & $4.50 \pm 1.24$ \\
\hline $\mathrm{Cl}^{-}\left(\right.$meq L $\left.{ }^{-1}\right)$ & $12.81 \pm 4.97$ & $3.55 \pm 1.45$ & $6.22 \pm 1.91$ \\
\hline $\mathrm{HCO}_{3}^{-}(\mathrm{meq} \mathrm{L}-1)$ & $6.45 \pm 0.82$ & $6.96 \pm 0.41$ & $6.33 \pm 1.20$ \\
\hline $\mathrm{NO}_{3}^{-}\left(\right.$meq L $\left.{ }^{-1}\right)$ & $0.12 \pm 0.09$ & $0.17 \pm 0.07$ & $0.07 \pm 0.06$ \\
\hline $\mathrm{SO}_{4}^{2-}\left(\mathrm{meq} \mathrm{L}^{-1}\right)$ & $4.99 \pm 1.87$ & $0.57 \pm 0.38$ & $0.85 \pm 1.08$ \\
\hline
\end{tabular}

- Group 1. Cenotes at the RC's west side.

+ Group 2. Cenotes at the center of the RC's.

- Group 3. Cenotes at the RC's east side.

gardens surrounding it. Likewise, in cenote 2 during the rainy season surface concentrations reached $0.81 \mathrm{meq} \mathrm{L}^{-1}$, probably as a result of contaminants washed from a farm adjacent to the site.

$\mathrm{Mg}^{2+}$ concentrations were highest in cenotes 1 through 7 in the west. This ion originates from seawater and dissolution of dolomite and evaporites (Custodio and Llamas, 1983, p. 1012), suggesting that the high concentrations could be due to seawater encroachment or the presence of dolomite and low-Mg calcite (Lefticariu et al., 2006).

$\mathrm{SO}_{4}^{2-}$ behavior was similar to that of $\mathrm{Mg}^{2+}$. Sulfate levels in cenote $7\left(4.74 \mathrm{meq} \mathrm{L}^{-1}\right)$ were 3.5 times higher than in cenote $9\left(1.35 \mathrm{meq} \mathrm{L}^{-1}\right)$. This disparity could be explained by the fact that the water in the west portion of the $\mathrm{RC}$ originates in the south near Chichancanab Lake, which has high $\mathrm{SO}_{4}^{2-}$ levels $\left(52.92 \mathrm{meq} \mathrm{L}{ }^{-1}\right.$ ) (Perry et al., 2002). Both cenotes are located in the area marking the watershed divide within the RC. This hydraulic separation of the RC was identified by Steinich et al. (1996) by using the $\mathrm{SO}_{4}^{2-} / \mathrm{Cl}^{-}$ratio, a natural tracer, in an analysis of hydrochemical and hydrogeological data to identify flow direction and the watershed divide in the southern portion of the RC. The $\mathrm{SO}_{4}^{2-}$ levels observed in the present study exhibited behavior similar to that of $\mathrm{SO}_{4}^{2-}$ in that study.

The $\mathrm{Ca}^{2+}$ and $\mathrm{HCO}_{3}^{-}$ions form part of the carbonate system. Fully understanding their behavior requires specific analyses and calculation of saturation indices for calcite, aragonite, and dolomite to identify chemical processes. Spatial patterns for each ion were determined within the RC. The highest $\mathrm{Ca}^{2+}$ concentrations were in the west, and $\mathrm{HCO}_{3}{ }^{-}$had higher concentrations in the center. Finally, nitrate-ion concentrations were highest in the center. This portion of the RC is a recharge area with dissolved oxygen levels that favor oxidation of nitrogenated species, and as a result, it carries large amounts of pollutants such as $\mathrm{NO}_{3}^{-}$. Overall, numerous differences were found along the $\mathrm{RC}$ that suggest regionalization of the aquifer in different areas.

\section{SeAsonal Trends}

The variables $\mathrm{pH}$, temperature, dissolved oxygen, $\mathrm{Ca}^{2+}$, $\mathrm{HCO}_{3}^{-}$, and $\mathrm{NO}_{3}^{-}$had significant statistical differences between seasons. Furthermore, electrical conductivity, temperature, dissolved oxygen, $\mathrm{Na}^{+}, \mathrm{Cl}^{-}$, and $\mathrm{NO}_{3}^{-}$clearly showed differences in spatial trends values between seasons. Electrical conductivity, $\mathrm{Na}^{+}$and $\mathrm{Cl}^{-}$increased at the RC's extremes (cenotes 1 to 4 in the west, cenotes 20 to 22 in the east) during the cold-fronts season due to movement of seawater into the coastal aquifer caused by sea level changes. The seawater intrusion threatens water availability for human consumption in this region (ValleLevinson et al., 2011). Arreguín (2008) proposed that due to the characteristics of the peninsula, sea-level rise could change the interface position, causing its gradual migration inland.

During the rainy and dry seasons, temperature decreased with depth, but this did not occur during the coldfronts season because ambient temperature is low, leading to homogeneous water column temperatures. Dissolved oxygen concentrations were higher and had less variability in the center compared to the edges during the cold-fronts season because low ambient temperature favors oxygen dissolution in the water column. Concentrations of $\mathrm{Na}^{+}$ and $\mathrm{Cl}^{-}$decreased at the RC's edges (cenotes 1 to 4 in the west, cenotes 20 to 22 in the east) during the rainy season due to dilution from aquifer recharge, a phenomenon also reported in groundwater (Cabrera, 1986; Cabrera et al., 2002). Nitrate concentrations increased during the rainy season as pollutants were washed into the aquifer (Pacheco and Cabrera, 1997; Pacheco et al., 2001). The chemical and physicochemical characteristics of the cenotes of the Yucatan Peninsula showed marked trends among seasons.

\section{Regionalization of the Ring of Cenotes}

The differences in chemical composition between water from the three groups of cenotes reflect distinct water sources. The first principal component (PC1) separated the 
Group 1 of cenotes from the other two based on increased conductivity and $\mathrm{Na}^{+}, \mathrm{Cl}^{-}$, and $\mathrm{SO}_{4}^{2-}$ concentrations compared to concentrations in Groups 2 and 3. High concentrations of $\mathrm{Na}^{+}, \mathrm{Cl}^{-}$, and $\mathrm{SO}_{4}^{2-}$ at Group 1 are associated with seawater, indicating that this group is characterized by seawater encroachment that can reach $55 \mathrm{~km}$ inland. Furthermore, high sulfate concentrations in this group can be explained by the preferential groundwater flow rich in sulfate from evaporites in the southern Yucatan Peninsula (Perry, 2002). Positive and negative scores from the principal component two (PC2) separated Group 2 from Group 3. Group 2 consisted of cenotes located at long distances from the shoreline that were characterized by low $\mathrm{pH}$ values, high $\mathrm{NO}_{3}^{-}$, and high $\mathrm{Ca}^{2+}$ and $\mathrm{HCO}_{3}^{-}$concentrations. The influence of the carbonate system is showed in $\mathrm{PC} 2$ through $\mathrm{Ca}^{2+}$ and $\mathrm{HCO}_{3}^{-}$ions, as well as $\mathrm{pH}$ values (Garrels and Christ, 1965). The low $\mathrm{pH}$ values in this group were likely to be a result of direct recharge from rain water, whose mean $\mathrm{pH}$ value in the regions is around 6 (Cabrera et al., 1996). This corroborates that Group 2, in the center of the $\mathrm{RC}$, is in an aquifer recharge zone. The cenotes in Group 3 exhibited high hydrochemical variability and were consequently distributed within both principal components. The variability of this group of cenotes is likely caused by groundwater flow from the east near the cenote 17 (Fig. 1). Cenotes nearer the coast were more similar in $\mathrm{PC} 1$ due to concentrations of $\mathrm{Na}^{+}$and $\mathrm{Cl}^{-}$similar to those of Group 1. The distances to the shoreline showed an influence on PC2, indicating that there was not a direct relationship with sea-water encroachment according to the spatial behavior of sodium and chloride ions reinforcing the differences between the cenotes from Groups 1 and 3 (Figs. 2a and 3a).

The PERMANOVA revealed the presence of an interaction between season and cenote groups. The paired tests revealed a dependence of seasons on groups but not vice versa, meaning inter-group differences were not season dependent; and therefore, regionalization is present year round. Paired tests also demonstrated that seawater encroachment in Group 1 and carbonate-system characteristics in Group 2 are identifiable in all three seasons. This is not the case in Group 3, since during the dry and cold-fronts seasons chemical processes change in response to environmental variables and the morphological and structural characteristics of each cenote. The CAP corroborated the existence of Groups 1,2 and 3; indeed, the CAP and PCA graphic results separated the groups in similar ways. This confirms that group separation was only the product of the maximum variation in chemical and physicochemical characteristics.

\section{CONCLUSIONS}

Multivariate statistical techniques were successfully applied to regionalize into three large regions twenty-two cenotes in the RC in the Mexican state of Yucatan based on water chemistry and physicochemical characteristics. Region 1 encompasses cenotes in the RC's western portion that have $\mathrm{Na}^{+}, \mathrm{Cl}^{-}$, and $\mathrm{K}^{+}$concentrations mainly associated with seawater encroachment, as well as high sulfate concentrations originating in the southern Yucatan Peninsula. Region 2 includes cenotes in the RC's center with slightly acid $\mathrm{pH}$ values, lower electrical conductivity, and lower ion $\left(\mathrm{Na}^{+}, \mathrm{K}^{+}, \mathrm{Mg}^{2+}, \mathrm{Cl}^{-}\right)$concentrations, evidence of weak influence from seawater and suggesting that this is an aquifer recharge zone. Region 3 includes cenotes in the RC's eastern portion characterized by higher $\mathrm{pH}$ values, high hydrochemical variability caused by groundwater flow from the east and less seawater encroachment. The RC regions associated with water characteristics may prove helpful when making management and conservation decisions such as the restriction of human activities, the selection of waste disposal areas, and the protection of recharge areas to help move to a sustainable use of the water resources in this geographical area.

\section{AcKNowledgments}

To Consejo Nacional de Ciencia y Tecnología (CONACYT) - Ciencias Básicas, México, for financial support through the project CB-2006-01-60126. The authors are grateful to anonymous reviewer for the important comments on the manuscripts. R. Pérez-Ceballos acknowledges a doctoral fellowship from CONACYT.

\section{REFERENCES}

Antigüedad, I., Morales, T., and Uriarte, J., 2007, Los acuíferos kársticos. Caso del pais Vasco: Enseñanza de las Ciencias de la Tierra, v. 5, no. 3 , p. 325-332.

APHA-AWWA-WPCF, 2005, Standard Methods for the Examination of Water and Wastewater: Washington, D.C., 21 Edition, 1368 p.

Arreguín Cortés, F.I., 2008, Evaluación de los efectos del Cambio Climático Global sobre el Ciclo Hidrológico en México, in Proceedings, XX Congreso Nacional de Hidráulica: Toluca, Estado de México, Comisión Nacional del Agua, p. 1-36.

Batllori-Sampedro, E., González-Piedra, J., Díaz-Sosa, J., and FeblesPatrón, J., 2006, Caracterización hidrológica de la región costera noroccidental del estado de Yucatán, México: Investigaciones Geográficas, Boletín del Instituto de Geografía, UNAM, no. 59, p. 74-92.

Cabrera, A., 1986, Hidrogeoquímica del agua subterránea en acuíferos cársticos, [M.S. thesis]: Universidad Autónoma de Yucatán, México, $76 \mathrm{p}$.

Cabrera, A., Pacheco, J., and Cobos, G., 1996, Caracterización química de la precipitación pluvial de la ciudad de Mérida Yucatán: Boletín académico, FIUADY, no. 30, p. 13-19.

Cabrera, A., Pacheco, J., Cuevas, E., Ramírez, J., Comas, M., and Cámara, A., 2002, Hidrogeoquímica del agua que subyace a la JAPAY I, en Mérida, Yucatán, México: Ingeniería Revista Académica, v. 6 , no. 3, p. 29-40.

Custodio, L., and Llamas, M., 1983, Hidrología subterránea: Barcelona, Spain, Ed. Omega, 2359 p.

Deutsch, W.J., 1997, Groundwater geochemistry, Fundamentals and Applications to Contamination: Boca Raton, Florida, CRC Press, $221 \mathrm{p}$.

Di Rienzo, J.A., Casanoves, F., Balzarini, M.G., Gonzalez, L., Tablada, M., and Robledo, C.W., 2008. InfoStat, versión 2008, Grupo InfoStat, FCA, Universidad Nacional de Córdoba, Argentina. 
Donado, L., 1999, Hidrogeoquímica, Hidrogeología con Aplicaciones y Casos de Estudios Latinoamericanos: Publicado en Internet, Editado por Gonzalo Pulido Silva, PhD. Capítulo 3.

Duch, G., 1991, Fisiografía del estado de Yucatán, su relación con la agricultura: Edo. México, Universidad Autónoma de Chapingo, $229 \mathrm{p}$.

Escolero, O., Marín, L., Steinich, B., Pacheco, J., Molina, A., and Anzaldo, J., 2005, Geochemistry of the hydrogeological reserve of Mérida, Yucatán, Mexico: Geofísica Internacional, v. 44, no. 3, p. $301-314$.

Fernández, R., Baquero, J.C., Lorca, D., and Verdejo, J., 2003, Acuíferos kársticos costeros, introducción a su conocimiento, in Memoria de TIAC'03 Tecnología de la Intrusión de Agua de Mar en Acuíferos Costeros: Países mediterráneos, Instituto Geológico y Minero de España y Diputación Provincial de Alicante, p. 3-30.

Gaona-Vizcayno, S., Gordillo-de Anda, T., and Villasuso-Pino, M., 1980, Cenotes, karst característico: Mecanismos de formación: UNAM, Revista Instituto de Geología, v. 4, no. 1, p. 32-36.

Garrels, R., and Christ, C., 1965, Solutions, minerals, and equilibria: New York, Harper and Row, $450 \mathrm{p}$.

Gobierno del Estado de Yucatán, 2008, Desarrollo Regional para el Crecimiento Equilibrado: Primer Informe de Gobierno de 2008, 92 p.

Hildebrand, A., Pilkington, M., Connors, M., Ortiz-Aleman, C., and Chavez, R., 1995, Size and structure of the Chicxulub crater revealed by horizontal gravity gradients and cenotes: Nature, v. 376, p. 415-417, doi:10.1038/376415a0.

Instituto Nacional de Estadística, Geografía e Informática (INEGI), 2002, Estudio Hidrológico del estado de Yucatán: Gobierno del Estado de Yucatán, México, 77 p.

Lefticariu, M., Perry, E.C., Ward, W., and Lefticariu, L., 2006, PostChicxulub depositional and diagenetic history of the northwestern Yucatan Peninsula, Mexico: Sedimentary Geology, v. 183, no. 1-2, p. 51-69, doi:10.1016/j.sedgeo.2005.09.008.

Marín, L., Pacheco, J., and Méndez, R., 2004, Hidrogeología de la península de Yucatán, in Jiménez, B., and Marín, L., eds., El Agua en México Vista desde la Academia: México, D.F., Academia Mexicana de Ciencias, p. 159-176.

Marín, L., and Perry, E., 1994, The hydrogeology and contamination potential of northwestern Yucatan, Mexico: Geofísica Internacional, v. 33, p. 619-623.

Melloul, A.J., and Goldenberg, L.C., 1998, Early-indicator signals of groundwater contamination: the case of seawater encroachment: Environmental Geology, v. 33, no. 4, p. 279-288, doi: 10.1007/ s002540050247.

Moore, P., Martin, J., and Screaton, E., 2009, Geochemical and statistical evidence of recharge, mixing, and controls on spring discharge in an eogenetic karst aquifer: Journal of Hydrology, v. 376, p. 443-455.

Pacheco, J., and Cabrera, A., 1997, Groundwater contamination by nitrates in the Yucatan Peninsula, Mexico: Hydrogeology Journal, v. 5, no. 2, p. 47-53, doi:10.1007/s100400050113.

Pacheco, J., Cabrera, A., and Pérez, R., 2004, Diagnóstico de la calidad del agua subterránea en los sistemas municipales de abastecimiento en el Estado de Yucatán, México: Ingeniería Revista Académica, v. 8, no. 2 , p. $165-179$.

Pacheco, J., Marín, L., Cabrera, S., Steinich, B., and Escolero, O., 2001, Nitrate temporal and spatial pattern in 12 water-supply wells, Yucatan, Mexico: Environmental Geology, v. 40, no. 6, p. 708-715, doi:10.1007/s002540000180.

Penfield, G., and Camargo, Z., 1981, Definition of a major igneous zone in the central Yucatan platform with aeromagnetics and gravity: Society of Exploration Geophysisists, 51 ${ }^{\text {st }}$ Annual International meeting, Los Angeles, Abstracts, $37 \mathrm{p}$.

Perry, E., Marin, L., McClain, J., and Velázquez, G., 1995, Ring of cenotes (sinkholes) northwest yucatan, Mexico: Its hydrogeologic characteristics and possible association with the Chicxulub impact crater: Geology, v. 23, no. 1, p. 17-20, doi:10.1130/0091-7613(1995) $023<0017$ :ROCSNY $>2.3$. CO 2 .

Perry, E., Paytan, A., Pedersen, B., and Velazquez-Oliman, G., 2009, Groundwater geochemistry of the Yucatan Peninsula, Mexico: Constraints on stratigraphy and hydrogeology: Journal of Hydrology, v. 367 , p. $27-40$.

Perry, E., Swift, J., Gamboa, J., Reeve, A., Sanborn, R., Marin, L., and Villasuso, M., 1989, Geologic and environmental aspects of surface cementation, north coast, Yucatan, Mexico: Geology, v. 17, no. 9, p. 818-821, doi:10.1130/0091-7613(1989)017<0818:GAEAOS $>2.3$. $\mathrm{CO} ; 2$.

Perry, E., Velazquez-Oliman, G., and Marin, L., 2002, The hydrogeochemistry of the karst aquifer system of the northern Yucatan Peninsula, Mexico: International Geology Review, v. 44, p. 191-221, doi:10.2747/0020-6814.44.3.191.

Secretaría de Agricultura y Recursos Hidráulicos (SARH), 1989, Sinopsis Geohidrológica del Estado de Yucatán: Subsecretaría de Infraestructura Hidráulica, Dirección General de Administración y Control de Sistemas Hidrológicos, $48 \mathrm{p}$.

Schmitter-Soto, J., Comín, F., Escobar-Briones, E., Herrera-Silveira, J., Alcocer, J., Suárez-Morales, E., Elías-Gutiérrez, M., Díaz-Arce, V., Marín, L., and Steinich, B., 2002, Hydrogeochemical and biological characteristics of cenotes in the Yucatan Peninsula (SE Mexico): Hydrobiologia, v. 467, no. 1-3, p. 215-228, doi:10.1023/A:10149232 17206.

Secretaría de Ecología (SECOL), 1999, Cenotes y Grutas de Yucatán: Gobierno del Estado de Yucatán: Mérida, Yucatán, México, Ed. CEPSA, $159 \mathrm{p}$.

Steinich, B., and Marín, L., 1997, Determination of flow characteristics in the aquifer of the northwestern peninsula of Yucatan, Mexico: Journal of Hydrology, v. 191, p. 315-331.

Steinich, B., Velázquez-Olimán, G., Marín, L., and Perry, E., 1996, Determination of the ground water divide in the karst aquifer of Yucatan, Mexico, combining geochemical and hydrogeological data: Geofísica Internacional, v. 35, p. 153-159.

Valle-Levinson, A., Mariño-Tapia, I., Enriquez, C., and Waterhouse, A., 2011, Tidal variability of salinity and velocity fields related to intense point-source submarine groundwater discharges into the coastal ocean: Limnology and Oceanography, v. 56, p. 1213-1224, doi: 10.4319/lo.2011.56.4.1213. 